\title{
LeishVet guidelines for the practical management of canine leishmaniosis
}

\author{
Laia Solano-Gallego ${ }^{1 *}$, Guadalupe Miró ${ }^{2}$, Alek Koutinas ${ }^{3}$, Luis Cardoso ${ }^{4}$, Maria Grazia Pennisi ${ }^{5}$, Luis Ferrer ${ }^{6}$, \\ Patrick Bourdeau', Gaetano Oliva ${ }^{8}$ and Gad Baneth ${ }^{9}$
}

\begin{abstract}
The LeishVet group has formed recommendations designed primarily to help the veterinary clinician in the management of canine leishmaniosis. The complexity of this zoonotic infection and the wide range of its clinical manifestations, from inapparent infection to severe disease, make the management of canine leishmaniosis challenging. The recommendations were constructed by combining a comprehensive review of evidence-based studies, extensive clinical experience and critical consensus opinion discussions. The guidelines presented here in a short version with graphical topic displays suggest standardized and rational approaches to the diagnosis, treatment, follow-up, control and prevention of canine leishmaniosis. A staging system that divides the disease into four stages is aimed at assisting the clinician in determining the appropriate therapy, forecasting prognosis, and implementing follow-up steps required for the management of the leishmaniosis patient.
\end{abstract}

\section{Background}

Canine leishmaniosis (CanL) due to Leishmania infantum is a major global zoonosis potentially fatal to humans and dogs, which comprise the main reservoir of infection to humans [1]. CanL is endemic in more than 70 countries in the world. It is present in regions of southern Europe, Africa, Asia, South and Central America [2] and has been reported also in the United States of America (USA) [3]. It is also an important concern in non-endemic countries where imported sick or infected dogs constitute a veterinary and public health problem [4].

CanL is manifested by a broad spectrum of clinical signs and degrees of severity, and there is insufficient scientific agreement on the management of this disease [2]. LeishVet is a group of veterinary scientists from academic institutes in Europe and the Mediterranean basin with a main clinical and scientific interest in CanL. The main goal of LeishVet is to develop consensus recommendations that would represent the most current understanding of $L$. infantum infection in dogs based on recent evidence-based literature and clinical experience [2]. The objective of these guidelines is to help

\footnotetext{
* Correspondence: Isolano@rvc.ac.uk

'Dep. Pathology and Infectious Diseases, Royal Veterinary College of London, UK

Full list of author information is available at the end of the article
}

practitioners in the clinical management of CanL with emphasis on diagnosis, clinical staging, treatment, clinical monitoring, prognosis and prevention.

\section{Life cycle and transmission}

Leishmania completes its life cycle in two hosts, a phlebotomine sand fly vector, which transmits the flagellated infective promastigote form, and a mammal, where the intracellular amastigote form develops and replicates (Figure 1). Sand flies are the only arthropods that are adapted for biological transmission of Leishmania. The relatively low proportion of sand flies harbouring $L$. infantum $(0.5-3 \%)$ is sufficient for maintaining the infection in endemic areas. Non-sand fly modes of transmission have also been described but their role in the natural history and epidemiology of leishmaniosis remains unclear (Figure 1). Proven modes of non-sand fly transmission include infection through transfused blood products [5] from blood donors which are carriers of infection [6,7], vertical [8-10] and venereal transmission [11]. The adequate selection of canine blood donors is of great importance for the prevention of L. infantum infection and recommendations on donor selection are graphically summarized in Figure 2. Suspected yet unproven modes of transmission include: 1) direct dogto-dog transmission through bites or wounds, which could explain the presence of autochthonous CanL
C Biomed Central

() 2011 Solano-Gallego et al; licensee BioMed Central Ltd. This is an Open Access article distributed under the terms of the Creative Commons Attribution License (http://creativecommons.org/licenses/by/2.0), which permits unrestricted use, distribution, and reproduction in any medium, provided the original work is properly cited. 


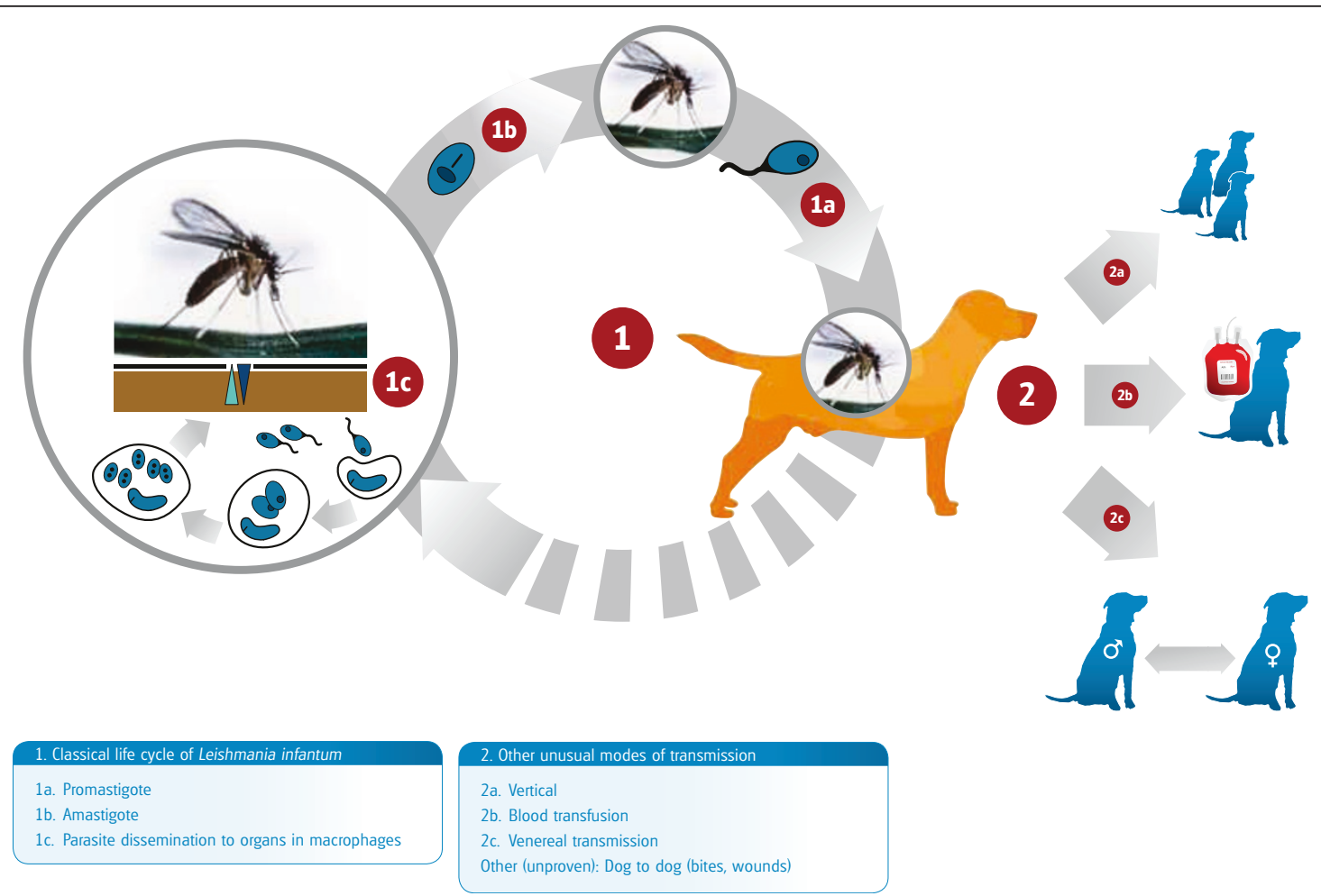

Figure 1 The life cycle of $L$. infantum with indication of proven and unproven non-sandfly routes of transmission to dogs.

\section{BLOOD DONOR CANDIDATE DOGS}

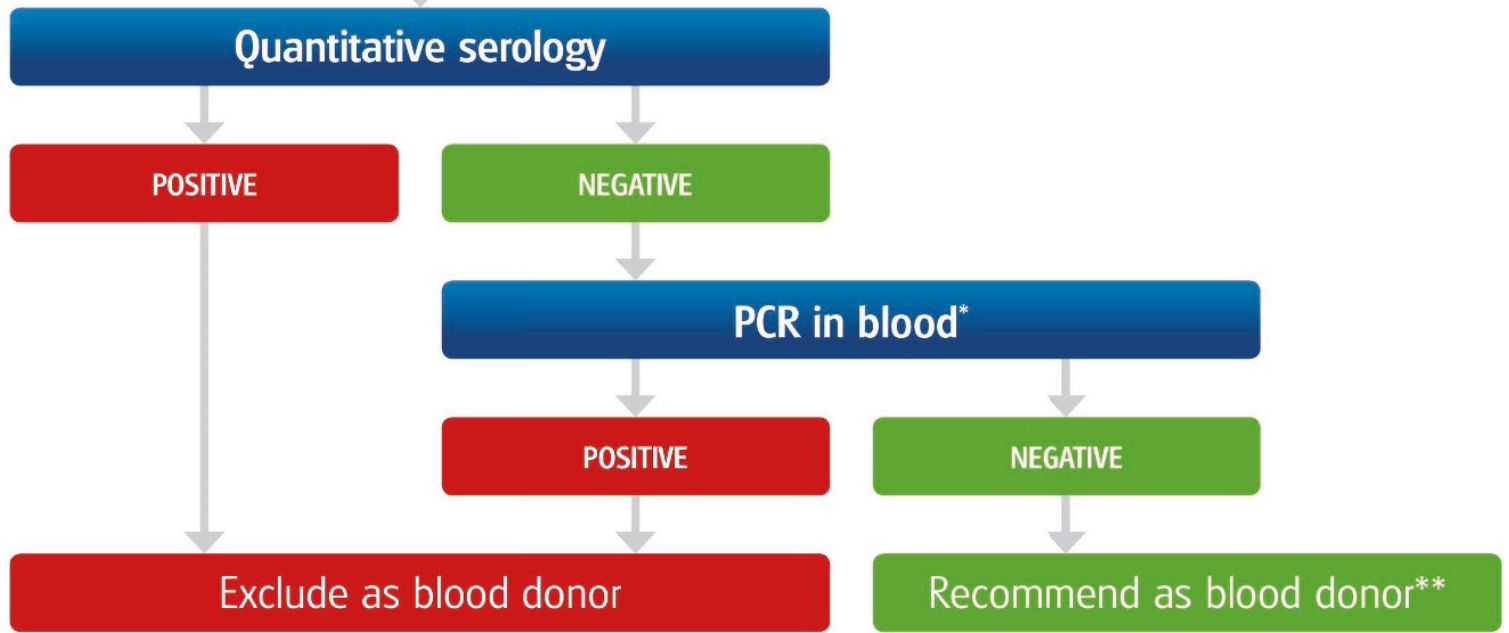

"If possible, it is recommended to test more than one tissue by PCR in addition to blood. Other tissues include bone marrow; lymph node; skin and the spleen.

${ }^{* *}$ It is recommended to perform a quantitative serology every 6 months for blood donors to ensure that they remain seronegative. Any blood that is used for transfusion should be PCR negative.

Figure 2 Algorithm describing the selection of blood donors and exclusion of infected dogs. Any dog infected will be excluded. 
clinical cases [12] in non-endemic areas in the absence of apparent vectors, as described in foxhounds in the USA [13] or in breeding kennels in Europe [14], and 2) transmission by other hematophagous arthropods such as ticks and fleas [15-21] (Figure 1).

\section{Distribution and epidemiology}

Socioeconomic and possible climate factors have led to changes in the distribution of CanL in Europe (Figure 3). Leishmania infantum infection has spread northward reaching the foothills of the Alps in northern Italy [22] and of the Pyrenees in France [14] and northern Spain [23]. The large numbers of dogs travelling to southern Europe or imported as companion animals from areas where CanL is endemic have increased the number of clinical cases reported in non endemic countries such as the United Kingdom [12] and Germany [24].

Leishmania infantum frequently follows an insidious and chronic pattern of infection [25]. Therefore, CanL is a disease in which infection does not equal clinical illness resulting in a high prevalence of subclinical infection $[2,26]$.

A broad range of immune responses and clinical manifestations have been described in CanL (Figure 4).
Infection in dogs may be subclinical or manifested as a self-limiting disease, or a severe, and sometimes, fatal illness [27]. Subclinical infection is not necessarily permanent and factors such as immunosuppression or concomitant diseases could break the equilibrium and lead to the progression of clinical disease in dogs [2,27] as observed in humans coinfected with human immunodeficiency virus and Leishmania [28].

Several predisposing factors for the development of disease have been described including breed, age and genetic background. Some dog breeds such as the Boxer, Cocker Spaniel, Rottweiler and German Shepherd seem to be more susceptible to the development of disease [29,30], while others such as the Ibizian Hound rarely develop clinical signs of CanL [31]. The Slc11c1 (Solute carrier family 11 member a1) gene, formerly named N-RAMPI, and certain alleles of the MHC II genes have been associated with susceptibility to CanL $[32,33]$. Age seems to be an important factor. The distribution of the disease is bimodal, with the highest prevalence reported in dogs younger than 3 years and older than 8 years $[34,35]$.

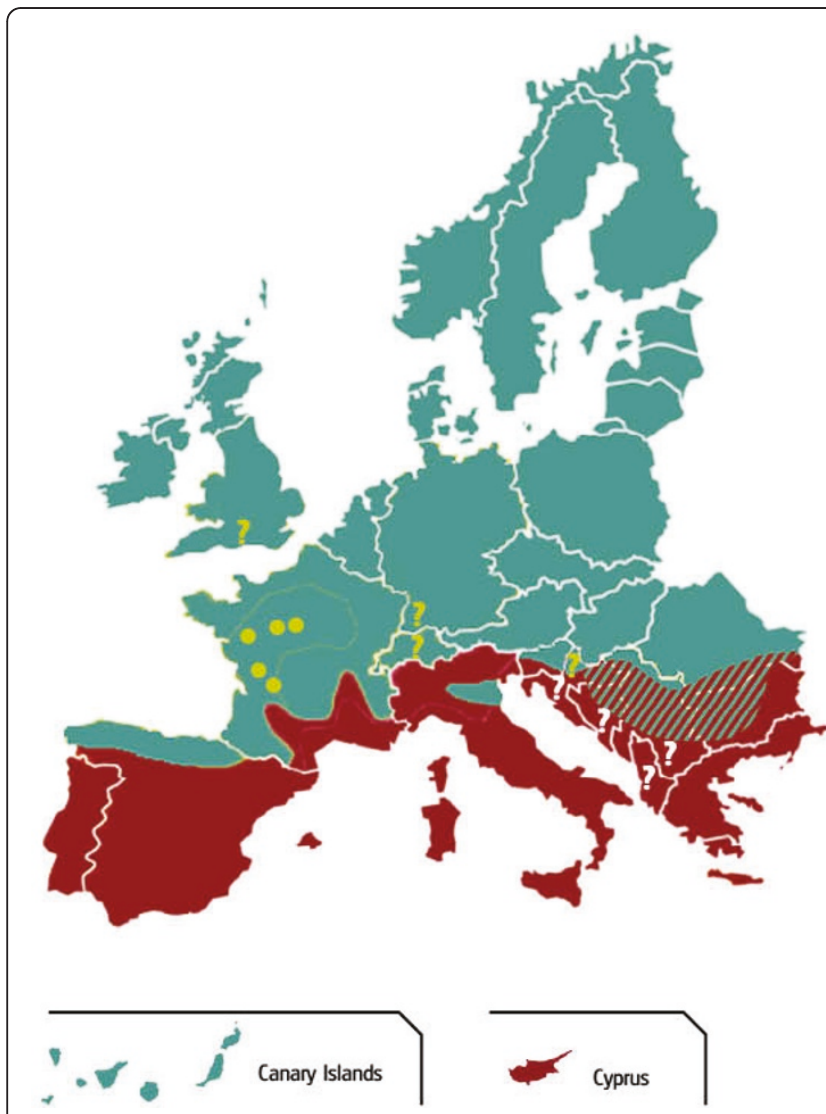

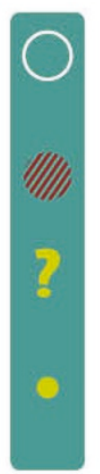

Non endemic areas

Countries or areas where cases are typically not autochthonous (traveling or imported dogs)

Potential areas

Expected presence of known vectors and clinical cases

Autochtonous cases

Rare individual cases that have never travelled to endemic areas (vectorial / non vectorial transmission?)

Autochthonous foci

(kennels with vectorial / non vectorial transmission?) (published or known by the authors)

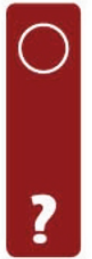

\section{Endemic areas}

Areas with multiple cases (abundant and active vectors) The prevalence and distribution of the disease are not uniform but highly dependent on microclimate and microhabitats

In many countries detailed information is still lacking

The northern limits of endemic areas are not well known. The limits presented are estimated according to the scientific literature and unpublished information 


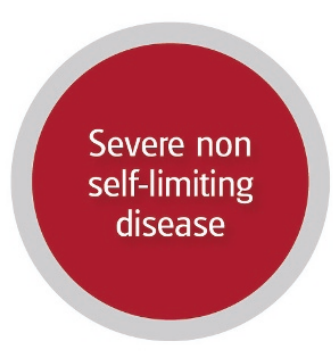

Th2 predominant response

- High serology

- Decreased cellular immunity

- High parasite load (dissemination of infection)

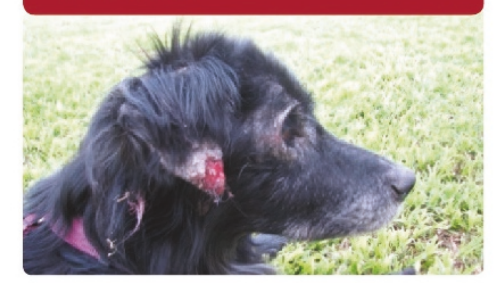

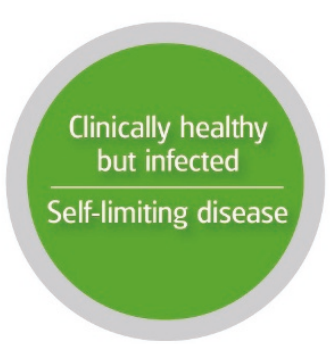

Th1 predominant response

- Low serology

- Predominant cellular immunity

- Low parasite load (control infection)

Leishmania infantum infection

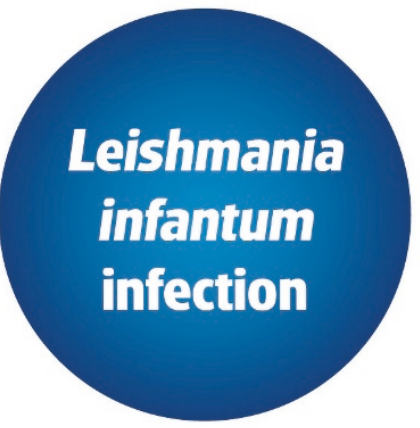

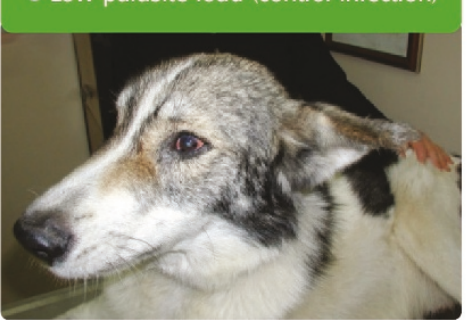

Figure 4 Clinical manifestations and immunological characteristics of $L$. infantum infection in dogs

\section{Clinical manifestations and laboratory abnormalities}

CanL is a systemic disease that may potentially involve any organ, tissue or body fluid and is manifested by nonspecific clinical signs. The most common clinical manifestations and clinicopathological abnormalities found in CanL are listed in Table 1[2,36,37]. Skin lesions are the most frequent manifestation among them (Figure 5) and may be seen along with other clinical signs or clinicopathological abnormalities. However, dogs can be presented with other clinical signs unrelated to cutaneous lesions as the main presenting complaint [36,37] (Figure 6). Renal disease may be the sole clinical manifestation of CanL and it can progress from mild proteinuria to the nephrotic syndrome or to an end stage renal disease. Chronic renal failure is a severe result of disease progression and the main cause of mortality due to CanL. Despite the high prevalence of renal pathology in infected dogs [38,39], renal azotemia is relatively an uncommon laboratory finding. The common pathological findings detected by cytology (Figure 7) or histology in CanL [40-43] are listed in Table 2. However, the variable and nonspecific clinical signs make the list of differential diagnoses wide and extensive.

\section{Diagnosis}

The purposes for which diagnosis of $L$. infantum infection is carried out are outlined in Figure 8. Due to these different diagnostic indications, it is important to separate Leishmania infection from disease and to apply different diagnostic techniques for each state. The definitions of sick versus clinically healthy infected dogs are shown in Figure 9 [27].

The diagnosis of CanL is complex as the clinical spectrum is broad and the range of clinicopathological abnormalities based on at least a complete blood count $(\mathrm{CBC})$, biochemical profile and urinalysis can be both wide and non-specific. A thorough clinicopathological diagnostic approach needs to be adapted for each patient when assessing the suspicion of this disease. In addition, dogs with leishmaniosis might be co-infected with other vector borne diseases or suffering from other concomitant infectious or non-infectious diseases making the differential diagnoses more complicated and diverse. Therefore, based on the clinicopathological problem list, a differential diagnosis and specific diagnostic approach would be made for each patient.

Different specific diagnostic methods have been described for the detection of $L$. infantum infection in dogs and these are shown in Figure 10. Valid diagnostic tests are essential for the detection of Leishmania infection in sick dogs although they lack $100 \%$ sensitivity and specificity [27]. The advantages and disadvantages of the different diagnostic methods are summarized in Table 3.

The diagnosis of CanL can be made by the detection of specific serum antibodies (IgG) using preferably quantitative serological techniques, such as the 
Table 1 Clinical manifestations and laboratory abnormalities found in canine leishmaniosis due to $L$. infantum

\begin{tabular}{|c|c|}
\hline Clinical manifestations & Laboratory abnormalities \\
\hline $\begin{array}{l}\text { General } \\
\circ \text { Generalized lymphadenomegaly } \\
\circ \text { Loss of body weight } \\
\circ \text { Decreased or increased appetite } \\
\circ \text { Lethargy } \\
\circ \text { Mucous membranes pallor } \\
\circ \text { Splenomegaly } \\
\circ \text { Polyuria and polydypsia } \\
\circ \text { Fever } \\
\circ \text { Vomiting } \\
\circ \text { Diarrhea (including chronic colitis) }\end{array}$ & $\begin{array}{l}\text { Serum proteins and electrophoretogram } \\
\text { Hyperglobulinemia } \\
\text { Polyclonal beta and/or gammaglobulinemia } \\
\circ \text { Hypoalbuminemia } \\
\circ \text { Decreased albumin/globulin ratio }\end{array}$ \\
\hline $\begin{array}{l}\text { Cutaneous } \\
\circ \text { Non-pruritic exfoliative dermatitis with or without alopecia } \\
\circ \text { Erosive-ulcerative dermatitis } \\
\circ \text { Nodular dermatitis } \\
\circ \text { Papular dermatitis } \\
\circ \text { Pustular dermatitis } \\
\circ \text { Onychogryphosis }\end{array}$ & $\begin{array}{l}\text { CBC/Hemostasis } \\
\circ \text { Mild to moderate non-regenerative anemia } \\
\circ \text { Leukocytosis or leukopenia } \\
\circ \text { Thrombocytopathy } \\
\circ \text { Thrombocytopenia } \\
\circ \text { Impaired secondary hemostasis and fibrinolysis }\end{array}$ \\
\hline $\begin{array}{l}\text { Ocular } \\
\text { Blepharitis (exfoliative, ulcerative, or nodular) and conjunctivitis (nodular) } \\
\circ \text { Keratoconjunctivitis, either common or sicca } \\
\circ \text { Anterior uveitis/Endophtalmitis }\end{array}$ & $\begin{array}{l}\text { Biochemical profile/urinalysis } \\
\text { Mild to severe proteinuria } \\
\circ \text { Renal azotemia } \\
\circ \text { Elevated liver enzyme activities }\end{array}$ \\
\hline $\begin{array}{l}\text { Other } \\
\text { Mucocutaneous and mucosal ulcerative or nodular lesions (oral, genital } \\
\text { and nasal) } \\
\circ \text { Epistaxis } \\
\circ \text { Lameness (erosive or non-erosive polyarthritis, osteomyelitis, polymyositis) } \\
\circ \text { Atrophic masticatory myositis } \\
\circ \text { Vascular disorders (systemic vasculitis, arterial thromboembolism) } \\
\circ \text { Neurological disorders }\end{array}$ & \\
\hline
\end{tabular}

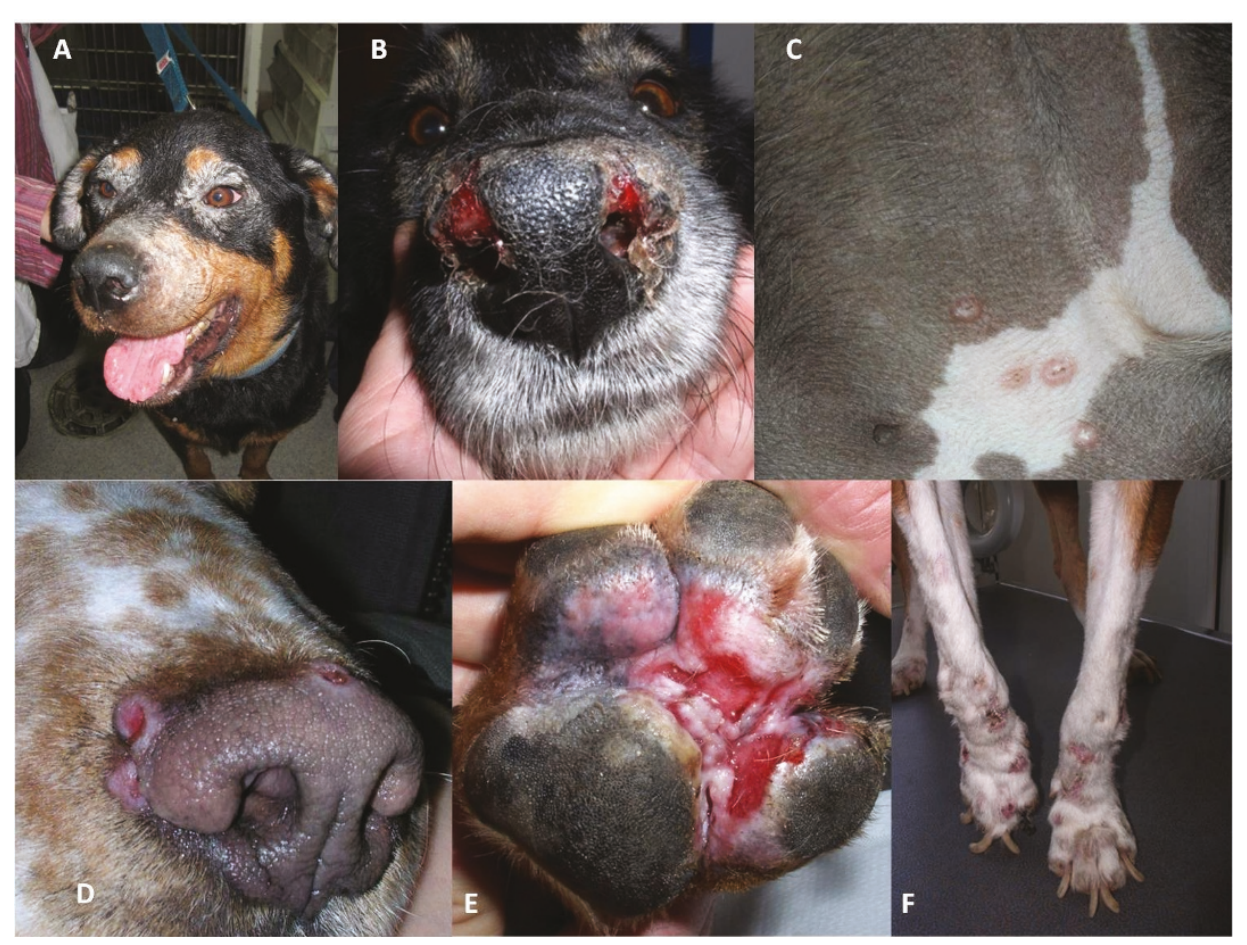

Figure 5 Different patterns of cutaneous lesions in CanL: A) Exfoliative periocular alopecia and blepharitis; B) Ulcerative nasal mucocutaneous lesions; C) Papular dermatitis in the inguinal region; D) Nodular crateriform lesions bordering the muzzle; E) Ulcerative erythematous lesions on the plantar surface of the paw and between pads; F) Onychogryphosis. 


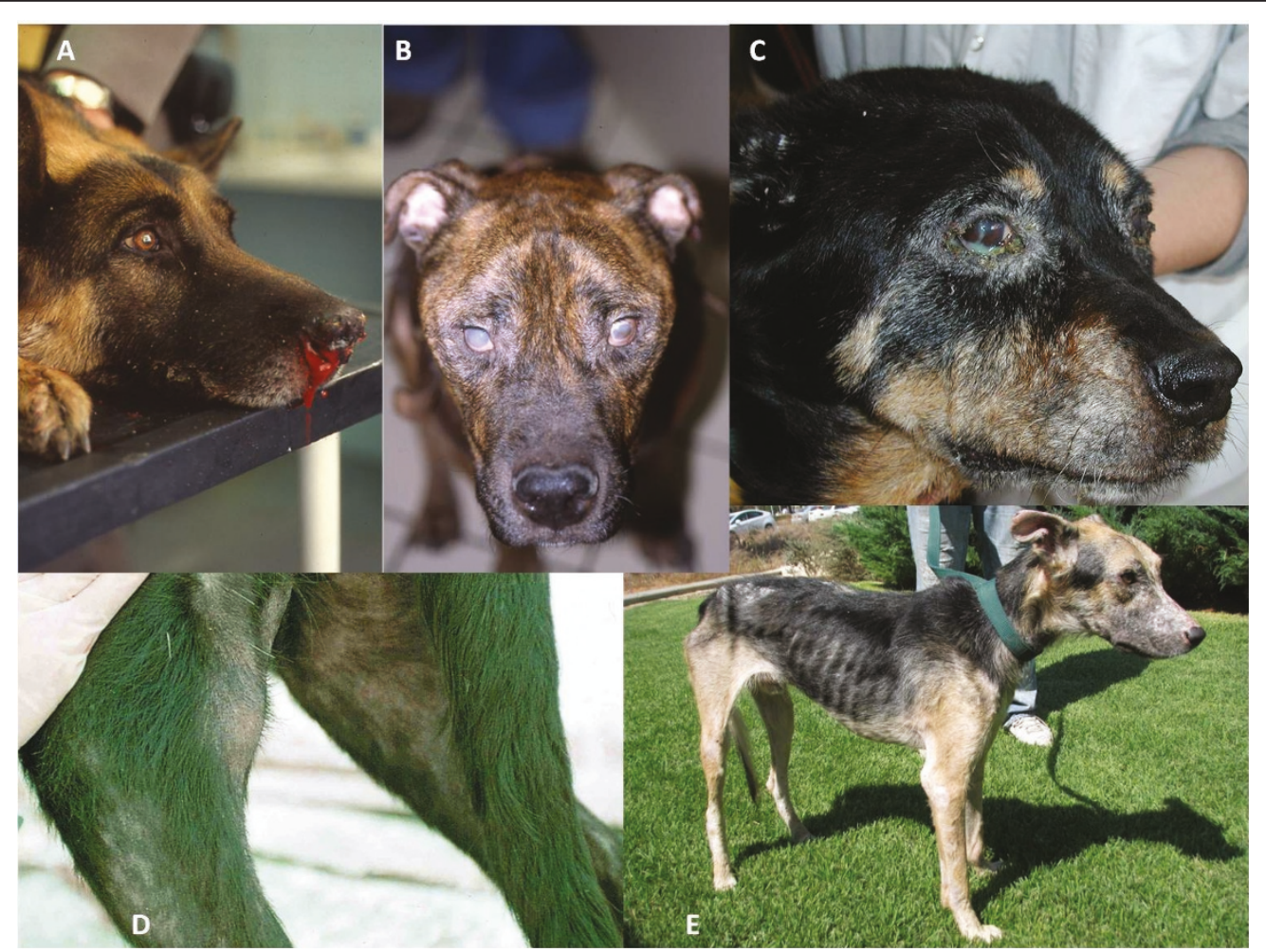

Figure 6 Some clinical signs found in CanL: A) Epistaxis; B) Bilateral uveitis and corneal opacity; C) Purulent conjunctivitis and blepharitis; D) Exfoliative alopecia in the rear leg and popliteal lymphadenomegaly; E) Marked cachexia and generalized exfoliative alopecia.

immunofluorescence antibody test (IFAT) and enzymelinked immunosorbent assay (ELISA). Immunochromatography-based assays are easy to use and provide rapid qualitative results on the spot, but their performance is still not optimal [44-46]. The interpretation of serological qualitative rapid tests is described in Figure 11. It is important to submit samples to a laboratory that runs quantitative serological assays and can provide an endpoint titer (IFAT) or an optical density reading (ELISA) and a classification of the level of antibodies [27].

Detection of Leishmania DNA in tissues by PCR allows sensitive and specific diagnosis of infection. PCR can be performed on DNA extracted from tissues, blood, body fluids or even from histopathologic specimens. The different sensitivities of tissues for the detection of L. infantum by PCR $[27,47,48]$ and variable sensitivities of PCR techniques are listed in Figure 12. Assays based on the detection of kinetoplast DNA (kDNA) appear to be the most sensitive for direct detection in infected tissues $[49,50]$. Real-time PCR allows quantification of the Leishmania parasite load in the tissues of infected dogs, which is useful for the diagnosis and the follow-up during treatment [51,52]. It is important to highlight that information provided by PCR should not be separated from the data obtained from clinicopathological and serological evaluations.
A high level of antibodies confirms the diagnosis of CanL in a dog with clinical signs and/or clinicopathological abnormalities compatible with leishmaniosis [53]. However, the presence of a low antibody level is not necessarily indicative of the disease and further work-up is necessary to confirm or exclude clinical leishmaniosis [27]. The diagnostic approach for sick dogs living in an endemic area is shown in Figure 13. The diagnostic approach for sick or healthy dogs living in a non-endemic area that have travelled to an endemic area, should include quantitative serology three months after the beginning of exposure in the endemic area.

\section{Clinical staging, treatment and prognosis}

A system of four clinical stages based on clinical signs, clinicopathological abnormalities and serological status was proposed by the LeishVet group in an effort to cover the wide spectrum of clinical manifestations and degrees of severity found in CanL [27]. Different treatment protocols and prognoses are suggested for each clinical stage as described in Table 4.

The most common drugs used for treatment of CanL, including dosage, combinations and side effects, are listed in Table 5. Several other candidate medications against CanL have been studied in vitro or in laboratory animals but rarely in controlled clinical trials and they 


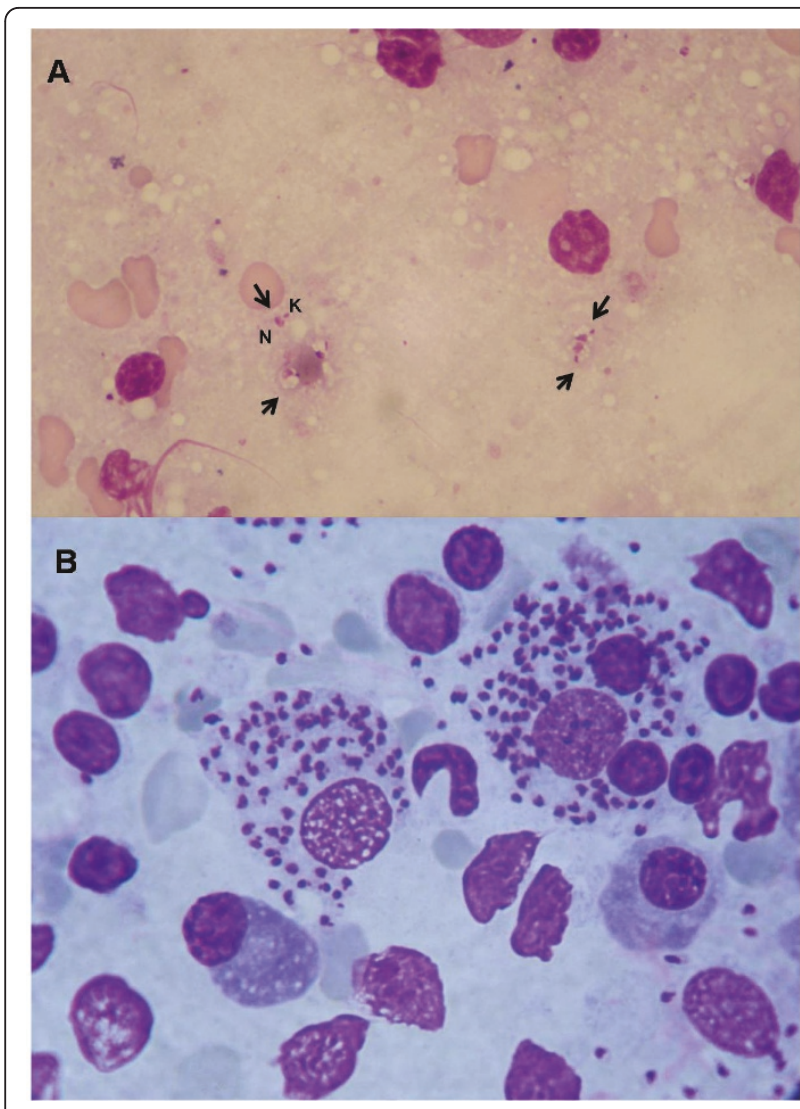

Figure 7 Interpretation of cytology A) Interpretation of cytology requires time and expertise for the detection of Leishmania amastigotes when parasites are in low numbers and freed from the cells. Note the nucleus $(\mathrm{N})$ and the kinetoplast $(\mathrm{K})$ of extracellular amastigotes (arrows) in a fine needle aspirate of a reactive lymph node from a dog with clinical leishmaniosis (x100, Diff-quick stain); B) High numbers of intracellular and extracellular Leishmania amastigotes in a fine needle aspirate of a reactive lymph node from a dog with clinical leishmaniosis (x100, modified Giemsa stain).

are, therefore, currently not recommended for the routine treatment of CanL [27].

The clinical response to treatment of sick dogs can vary from poor to good depending on their overall initial clinicopathological status and their specific response to therapy. Dogs with renal insufficiency are

Table 2 Cytological and histopathological patterns suggestive of canine $L$. infantum infection found in organs or body fluids.

\begin{tabular}{c}
\hline Pathological findings in organs or body fluids \\
$\checkmark$ Macrophagic inflammation (granulomatous) \\
$\checkmark$ Neutrophilic-macrophagic inflammation (pyogranulomatous) \\
$\checkmark$ Reactive hyperplasia in lymphoid organs \\
$\checkmark$ No evidence or variable numbers of intracellular or extracellular \\
Leishmania amastigotes
\end{tabular}

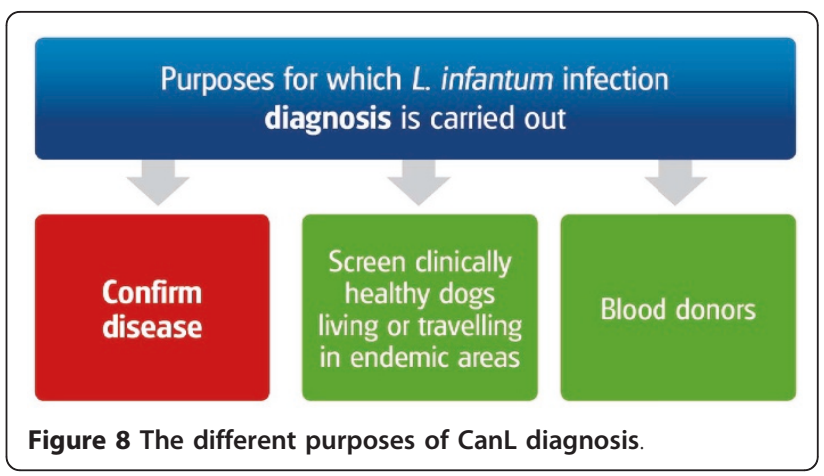

expected to have a lower recovery rate in comparison to those without kidney compromise or only mild proteinuria. Therapy with antileishmanial drugs often leads to clinical cure [54] although treated dogs may continue to harbour the parasite and be infectious to sand flies, but to a lesser extent than pre-treatment [52,55-57].

The vast majority of dogs experience clinical improvement within the first month of therapy [51,52,58]; however, a longer period of therapy may be required for others before improvement is apparent. The frequencies of monitoring and clinicopathological parameters, including serology, to be followed up during treatment of CanL are summarized in Table 6.

The length of allopurinol treatment depends on the severity of the disease, the clinical and parasitological response to treatment and the individual tolerance to this drug. Some extremely susceptible dogs never reach a point that would allow the discontinuation of allopurinol, while others are capable of controlling infection without the need for extremely lengthy treatment [27]. Allopurinol can be discontinued when the combination of the following criteria is made:

(1) The presence of complete physical and clinicopathological recovery evaluated by a thorough physical examination, $\mathrm{CBC}$, full biochemistry panel and urinalysis.

(2) A marked decrease of antibody levels (to negative or borderline by a quantitative serological assay).

In addition, allopurinol might be discontinued if it is not possible to control or decrease the xanthinuria with low purine diets or by reducing the drug's dosage, to avoid the risk of urolithiasis, if massive xanthine crystalluria is present [59].

\section{Management of clinically healthy infected dogs in endemic areas}

The management of clinically healthy infected dogs in areas where CanL is endemic is of great importance for practitioners. 


\section{Clinical classification: physical exam and laboratory tests}
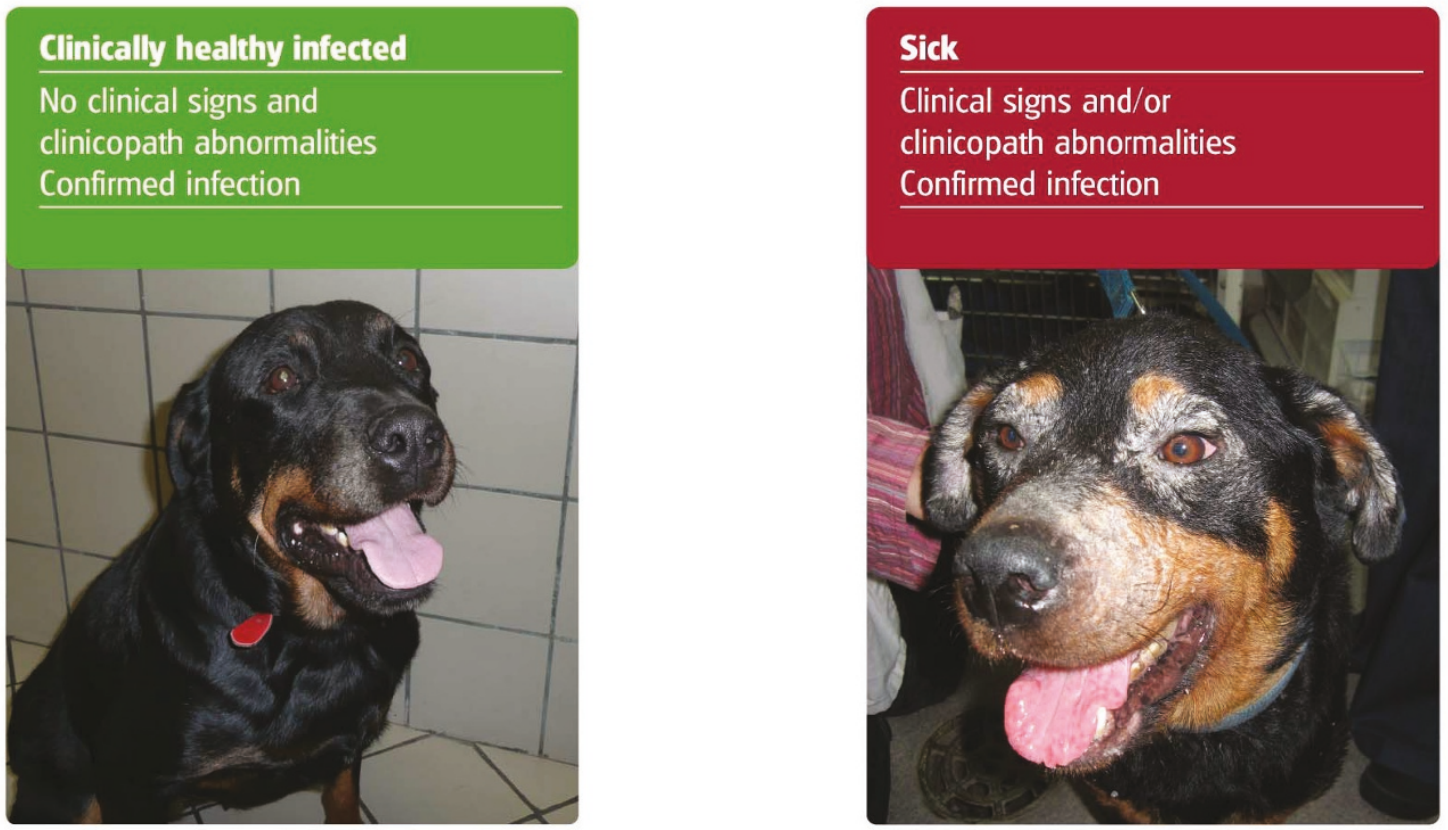

Figure 9 Definition of $\boldsymbol{L}$. infantum-infected but healthy versus sick dogs. Dogs with clinical leishmaniosis are defined as those presenting clinical signs and/or clinicopathological abnormalities and having a confirmed $L$. infantum infection. Dogs with subclinical infection, or clinically healthy but infected dogs, are defined as those that present neither clinical signs on physical examination nor clinicopathological abnormalities by routine laboratory tests (CBC, biochemical profile and urinalysis) but have a confirmed L. infantum infection.

The presence of Leishmania DNA in the blood or other tissues of clinically healthy dogs living in endemic areas indicates that these dogs harbour infection [26], but they may never develop clinical disease [60]. In contrast, a high positive antibody titer may indicate that an infected dog is heading towards the development of a widespread infection and future development of clinical disease [53]. Therefore, we recommend using serology alone or the combination of serology with PCR for screening healthy dogs. It is recommended to avoid screening clinically healthy dogs only by PCR.

Healthy dogs should be screened for Leishmania antibodies as an initial indication for the presence of infection if [27]:

1. They are scheduled to travel or be exported to non-endemic areas (Figure 14)

2. They serve as blood donors (Figure 2)

3. Their owners wish to have them monitored at least every 12 months for early detection of infection and the potential to develop disease.
PCR should be used for the second above indication and as an ancillary test for the first and third above indications.

The management of a clinically healthy seropositive dog and a clinically healthy seronegative and PCR-positive dog is summarized in Figure 14.

\section{Prevention}

Current preventative measures are mainly based on the use of veterinary registered products containing synthetic pyrethroids, permethrin, or deltamethrin with a repellent effect against sand flies whose efficacy has been demonstrated both experimentally [61-63] and in field studies [64-68]. These products are available in spot on formulation or in a collar form and they reduce the risk of new infections and the biting of sand flies on already infected dogs [64-68]. Other measures useful in the prevention of sand fly bites include [69,70]: 1) keeping the dog indoors during the sand fly season from dusk to dawn; 2) reducing microhabitats favourable to sand flies such as piles of wood and 


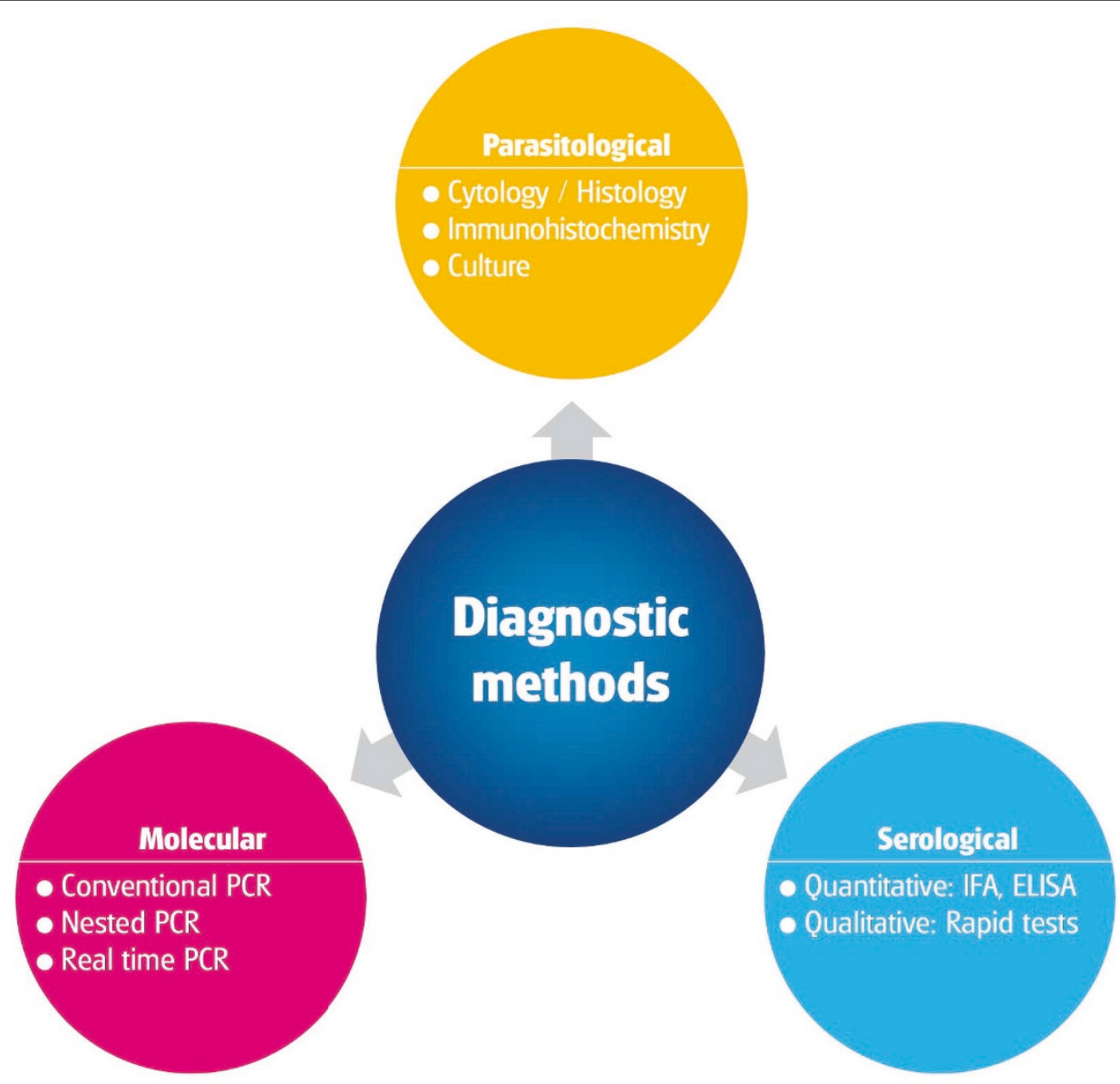

Figure 10 The most common diagnostic methods for CanL.

stones in the vicinity of the house and in other locations where dogs spend time; 3 ) usage of indoor insecticide treatment [27].

Long-acting topical insecticides evaluated in several published field studies [64-68] should be applied to dogs living or travelling to endemic areas as follows:

- Permethrin/Imidacloprid spot on formulation: Treatment provides repellent (anti feeding) activity against sand flies (P. perniciosus) for three weeks [61]. Repeat administration every 3 weeks. It should be applied at least 2 days before travelling

- Deltamethrin collars: Control of feeding by phlebotomine sand flies (P. perniciosus) for a period of 5-6 months [63]. Replace collar every 5-6 months. It should be applied at least 1-2 weeks before travelling.

Veterinarians and dog owners are advised to carefully check the product's label recommendations and follow the manufacturer's instructions for the correct application and frequency of reapplication. Client education on the maintenance of an appropriate insecticide [27] throughout the period of sand fly activity in the Mediterranean basin (April-November) is also crucial for the protection of dogs [71].

Purified Leishmania fraction vaccines appear currently to be the most effective and promising vaccines for dogs. These include the "fucose mannose ligand" (FML)-based vaccine [72,73] and an excreted/secreted antigen purified from specific-medium culture supernatant of L. infantum based vaccine [74]. The FML-based vaccine is currently available commercially in Brazil. The same vaccine has also been proposed as a transmission-blocking vaccine [75]. Recently, another vaccine which contains the recombinant A2 protein and saponin as adjuvant has also been approved in Brazil [76]. In Europe, a different vaccine based on cultured $L$. infantum purified excreted/secreted antigens has been approved for vaccination of dogs [74].

The future for CanL control should be an integrated approach to prevention including vaccination against $L$. infantum with an effective canine vaccine and the use of long-acting topical insecticide applications. A vaccine would prevent the establishment of infection introduced 
Table 3 Advantages and disadvantages of common diagnostic methods for the detection of $L$. infantum infection in dogs

\begin{tabular}{|c|c|c|}
\hline $\begin{array}{l}\text { DIAGNOSTIC } \\
\text { TECHNIQUES }\end{array}$ & ADVANTAGES & DISADVANTAGES \\
\hline SEROLOGY & $\begin{array}{l}\text { - Determination of antibody level which is essential for the } \\
\text { diagnosis and establishing a prognosis }\end{array}$ & $\begin{array}{l}\text { - Does not detect the actual presence of the Leishmania } \\
\text { parasite } \\
\text { - Serocrossreactions with trypanosomes }\end{array}$ \\
\hline QUALITATIVE & - Rapid in-clinic test & $\begin{array}{l}\text { - Provides only positive or negative result } \\
\text { - Variable sensitivities and performance with risk of false } \\
\text { negatives } \\
\text { - A positive result needs to be further evaluated by a } \\
\text { quantitative serology }\end{array}$ \\
\hline $\begin{array}{l}\text { QUANTITATIVE } \\
\text { (IFAT, ELISA) }\end{array}$ & $\begin{array}{l}\text { Determines the antibody level } \\
\text { - High antibodies levels in the presence of compatible clinical } \\
\text { signs and/or clinicopathological abnormalities are conclusive } \\
\text { of clinical leishmaniosis }\end{array}$ & $\begin{array}{l}\text { - Performance and accuracy of cut-off will depend on the } \\
\text { laboratory } \\
\text { - Differences between laboratories and poor standardization of } \\
\text { techniques } \\
\text { - Low antibody levels will require further work-up }\end{array}$ \\
\hline $\begin{array}{l}\text { CYTOLOGY/ } \\
\text { HISTOPATHOLOGY }\end{array}$ & $\begin{array}{l}\text { Permits direct detection of the parasite itself and the type of } \\
\text { pathological findings: } \\
\text { - Pathological findings suspicious of infection } \\
\text { - Allows exclusion of other differential diagnoses } \\
\text { - Rapid and non invasive (cytology) }\end{array}$ & $\begin{array}{l}\text { - Low sensitivity for the detection of Leishmania amastigotes in } \\
\text { tissues or body fluids } \\
\text { - Requires the performance of other diagnostic tests such as } \\
\text { immunohistochemistry and/or PCR when parasites are not } \\
\text { visualized } \\
\text { - Does not reveal the immunological status of the dog } \\
\text { - Needs expertise }\end{array}$ \\
\hline$\overline{P C R}$ & $\begin{array}{l}\text { - Allows the detection of leishmanial DNA } \\
\text { - High sensitivity (kDNA) and specificity } \\
\text { - Parasitic load quantification (if Real time-PCR) }\end{array}$ & $\begin{array}{l}\text { - False positive results possible due to DNA contamination } \\
\text { - Different standardization and techniques used by different } \\
\text { diagnostic laboratories } \\
\text { - Does not reveal immunological status } \\
\text { - It cannot be performed as the sole diagnostic technique for } \\
\text { the confirmation of the disease because a positive result } \\
\text { confirms Leishmania infection but not disease }\end{array}$ \\
\hline $\begin{array}{l}\text { PARASITE } \\
\text { CULTURE }\end{array}$ & $\begin{array}{l}\text { - Permits the isolation of Leishmania parasites } \\
\text { - Facilitates the isoenzymatic identification of the parasite }\end{array}$ & $\begin{array}{l}\text { - Time-consuming and laborious diagnostic technique } \\
\text { - It can require one month to provide a result } \\
\text { - Performed only in research laboratories }\end{array}$ \\
\hline
\end{tabular}

by the bites of those sand flies that escape the insecticide effect [50].

\section{Public health considerations}

In Southern Europe, human visceral leishmaniosis caused by L. infantum is a zoonotic disease that affects young children or adults suffering from the Acquired Immune Deficiency Syndrome (AIDS) or immunosuppressive conditions $[77,78]$. Dogs are considered the most important peridomestic reservoir of L. infantum infection for humans. However, the ownership of an infected dog does not appear to greatly increase the risk

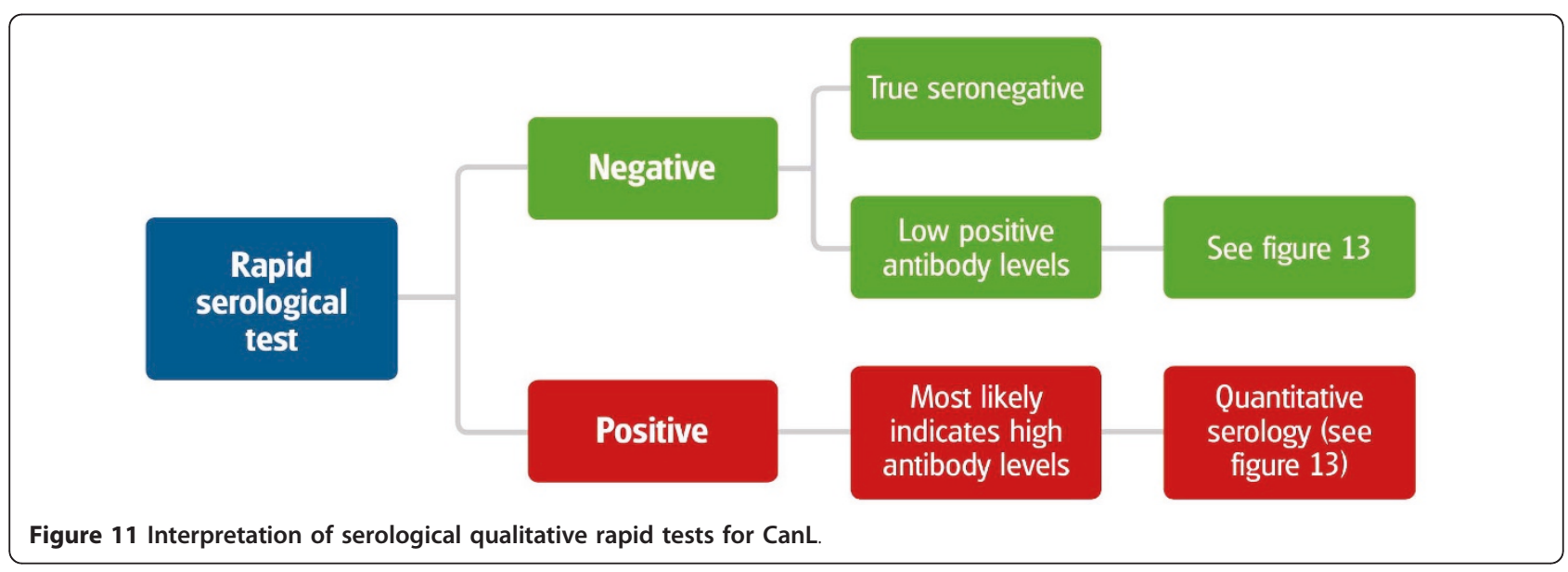




\section{What samples and techniques should be used for PCR?}

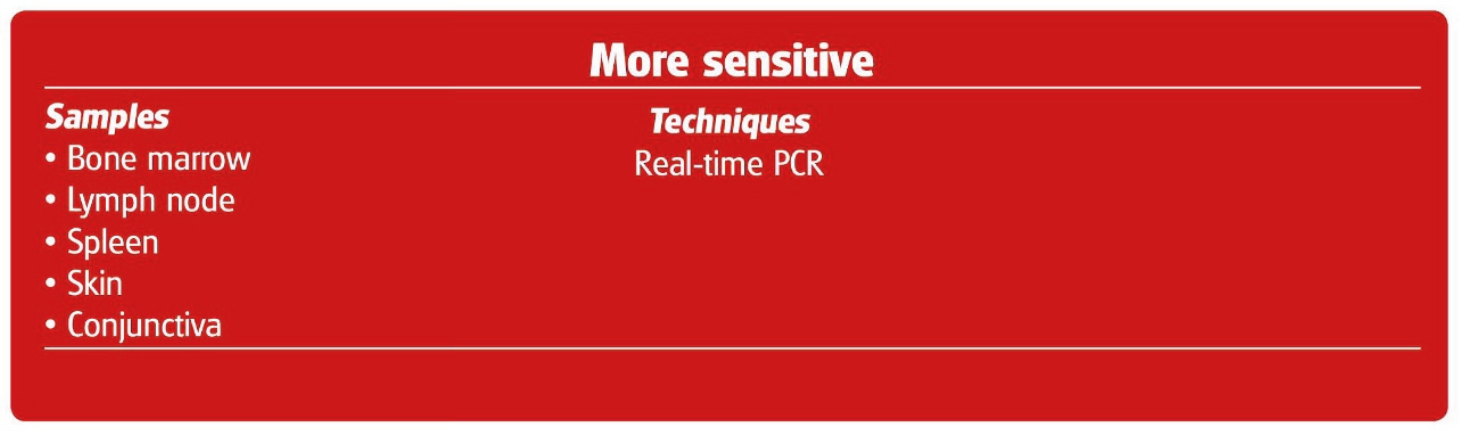

\section{Less sensitive}

Samples

Techniques

- Blood

Nested PCR; Conventional PCR

- Buffy coat

- Urine

Figure 12 Selection of tissues to be used for PCR and types of PCR techniques when suspecting CanL.

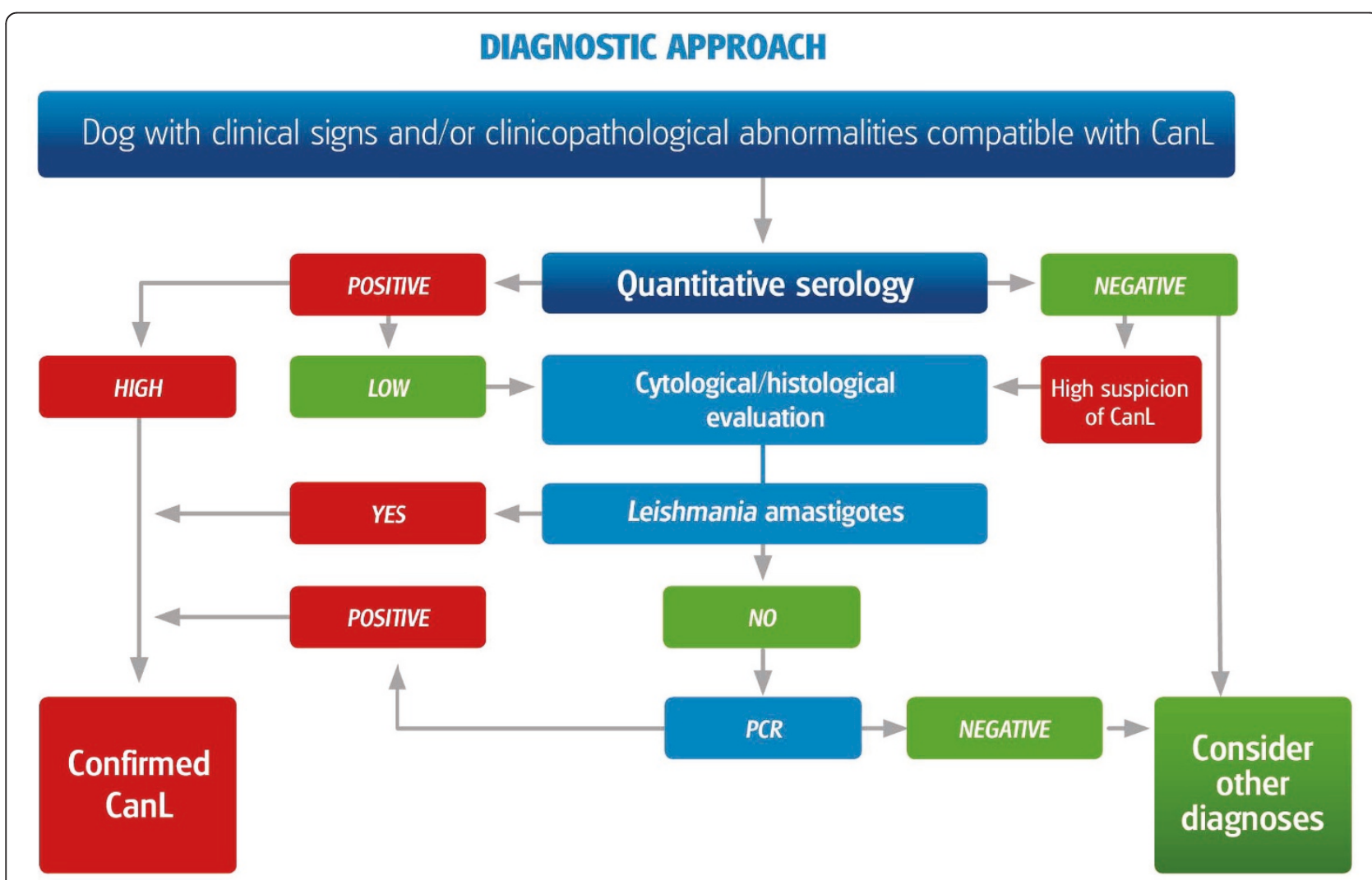

Figure 13 Flow chart for the diagnostic approach to dogs with suspected clinical signs and/or clinicopathological abnormalities consistent with CanL. 
Table 4 Clinical staging of canine leishmaniosis based on serological status, clinical signs, laboratory findings, and type of therapy and prognosis for each stage [27]

\begin{tabular}{|c|c|c|c|c|c|}
\hline $\begin{array}{l}\text { Clinical } \\
\text { stages }\end{array}$ & Serology $*$ & Clinical signs & Laboratory findings & Therapy & Prognosis \\
\hline $\begin{array}{l}\text { Stage I } \\
\text { Mild } \\
\text { disease }\end{array}$ & $\begin{array}{l}\text { Negative to } \\
\text { low positive } \\
\text { antibody } \\
\text { levels }\end{array}$ & $\begin{array}{l}\text { Dogs with mild clinical signs such } \\
\text { as peripheral lymphadenomegaly, } \\
\text { or papular dermatitis }\end{array}$ & $\begin{array}{l}\text { Usually no clinicopathological } \\
\text { abnormalities observed } \\
\text { Normal renal profile: creatinine < } \\
1.4 \mathrm{mg} / \mathrm{dl} \text {; non-proteinuric: } \\
\text { UPC < } 0.5\end{array}$ & $\begin{array}{l}\text { Scientific neglect/allopurinol or } \\
\text { meglumine antimoniate or } \\
\text { miltefosine/allopurinol }+ \\
\text { meglumine antimoniate or } \\
\text { allopurinol + miltefosine }\end{array}$ & Good \\
\hline $\begin{array}{l}\text { Stage II } \\
\text { Moderate } \\
\text { disease }\end{array}$ & $\begin{array}{l}\text { Low to high } \\
\text { positive } \\
\text { antibody } \\
\text { levels }\end{array}$ & $\begin{array}{c}\text { Dogs, which apart from the signs } \\
\text { listed in stage I, may present: } \\
\text { diffuse or symmetrical cutaneous } \\
\text { lesions such as exfoliative } \\
\text { dermatitis/onychogryphosis, } \\
\text { ulcerations (planum nasale, } \\
\text { footpads, bony prominences, } \\
\text { mucocutaneous junctions), } \\
\text { anorexia, weight loss, fever, and } \\
\text { epistaxis }\end{array}$ & $\begin{array}{l}\text { Clinicopathological abnormalities } \\
\text { such as mild non-regenerative } \\
\text { anemia, hyperglobulinemia, } \\
\text { hypoalbuminemia, serum } \\
\text { hyperviscosity syndrome } \\
\text { Substages } \\
\text { a) Normal renal profile: } \\
\text { creatinine }<1.4 \mathrm{mg} / \mathrm{dl} \text {; non- } \\
\text { proteinuric: UPC }<0.5 \\
\text { b) Creatinine }<1.4 \mathrm{mg} / \mathrm{dl} \text {; } \\
\text { UPC }=0.5-1\end{array}$ & $\begin{array}{l}\text { Allopurinol + meglumine } \\
\text { antimoniate or allopurinol+ } \\
\text { miltefosine }\end{array}$ & $\begin{array}{l}\text { Good to } \\
\text { guarded }\end{array}$ \\
\hline $\begin{array}{l}\text { Stage III } \\
\text { Severe } \\
\text { disease }\end{array}$ & $\begin{array}{l}\text { Medium to } \\
\text { high positive } \\
\text { antibody } \\
\text { levels }\end{array}$ & $\begin{array}{l}\text { Dogs, which apart from the signs } \\
\text { listed in stages I and II, may } \\
\text { present signs originating from } \\
\text { immune-complex lesions: vasculitis, } \\
\text { arthritis, uveitis and } \\
\text { glomerulonephritis. }\end{array}$ & $\begin{array}{l}\text { Clinicopathological abnormalities } \\
\text { listed in stage II } \\
\text { Chronic kidney disease (CKD) IRIS } \\
\text { stage I with UPC }>1 \text { or stage II } \\
\text { (creatinine } 1.4-2 \mathrm{mg} / \mathrm{dl} \text { ) [79] }\end{array}$ & $\begin{array}{c}\text { Allopurinol + meglumine } \\
\text { antimoniate or allopurinol + } \\
\text { miltefosine } \\
\text { Follow IRIS guidelines for CKD } \\
{[80]}\end{array}$ & $\begin{array}{l}\text { Guarded } \\
\text { to poor }\end{array}$ \\
\hline $\begin{array}{l}\text { Stage IV } \\
\text { Very } \\
\text { severe } \\
\text { disease }\end{array}$ & $\begin{array}{l}\text { Medium to } \\
\text { high positive } \\
\text { antibody } \\
\text { levels }\end{array}$ & $\begin{array}{c}\text { Dogs with clinical signs listed in } \\
\text { stage III. Pulmonary } \\
\text { thromboembolism, or nephrotic } \\
\text { syndrome and end stage renal } \\
\text { disease }\end{array}$ & $\begin{array}{c}\text { Clinicopathological abnormalities } \\
\text { listed in stage II } \\
\text { CKD IRIS stage III (creatinine 2-5 } \\
\text { mg/dl) and stage IV (creatinine > } \\
5 \mathrm{mg} / \mathrm{dl} \text { ) [79] Nephrotic } \\
\text { syndrome: marked proteinuria } \\
\text { UPC > } 5\end{array}$ & $\begin{array}{l}\text { Allopurinol (alone) } \\
\text { Follow IRIS guidelines for CKD } \\
{[80]}\end{array}$ & Poor \\
\hline
\end{tabular}

*Dogs with negative to medium positive antibody levels should be confirmed as infected by other diagnostic techniques such as cytology, histology, immunohistochemistry or PCR. High levels of antibodies, defined as a 3-4 fold elevation above the cut off level of a well established reference laboratory, are conclusive of a diagnosis of CanL. **Dogs in stage I (mild disease) are likely to require less prolonged treatment with one or two combined drugs or alternatively monitoring with no treatment. However, there is limited information on dogs in this stage and, therefore, treatment options remain to be defined.

of disease in the family when transmission is already present in the region [50].

\section{Conclusions}

The complexity of CanL and the wide range of its clinical manifestations, from inapparent infection to severe disease, make the management of CanL challenging. Diagnosis is performed based on clinicopathological manifestations and by confirmation of infection using mainly serological and molecular techniques. A staging system that divides the disease into four stages is aimed at assisting the clinician in determining the appropriate therapy, forecasting prognosis, and implementing follow-up steps required for the management of the leishmaniosis patient. Prevention should be an integrated approach including vaccination against $L$. infantum with

Table 5 Current treatment protocols for canine leishmaniosis [27]

\begin{tabular}{|c|c|c|c|}
\hline Drugs & Dosages & Main side effects & References \\
\hline Meglumine antimoniate* & 75-100 mg/kg once a day or 40-75 mg/kg twice a day for 4 weeks, S.C.** & $\begin{array}{c}\text { Potential nephrotoxicity } \\
\text { Cutaneous abscesses/cellulitis }\end{array}$ & {$[52,55,57,81-83]$} \\
\hline Miltefosine ${ }^{*}$ & $2 \mathrm{mg} / \mathrm{kg} /$ once a day for 28 days P.O. & Vomiting Diarrhea & [83-85] \\
\hline Allopurinol & 10 mg/kg twice a day for at least 6-12 months P.O. & Xanthine urolithiasis & {$[51,59,86-89]$} \\
\hline
\end{tabular}

* Registered for veterinary use in most European countries; both drugs are commonly recommended in combination with allopurinol.

P.O.: per os; S.C.: subcutaneous

**Treatment prolongation by 2-3 weeks may be considered if patient improvement is insufficient. 
Table 6 Treatment of canine leishmaniosis - recommended monitoring of clinicopathological parameters and serology including frequency of follow up [27]

\begin{tabular}{ll}
\hline Parameters & Frequency \\
\hline Clinical history and complete physical examination & After the first month of treatment and then every 3-4 months during the first \\
Routine laboratory tests: & year. Later on, if the dog is fully recovered clinically with treatment, a recheck \\
would be recommended every 6 months or once a year.
\end{tabular}

Complete CBC, biochemical profile, serum electrophoresis (optional) and complete urinalysis including UPC in proteinuric dogs.

\begin{tabular}{ll}
\hline Serology* & $\begin{array}{l}\text { Not before } 6 \text { months after initial treatment and every } 6 \text { months or once a } \\
\text { year thereafter. }\end{array}$ \\
\hline Real time PCR & $\begin{array}{l}\text { Can optionally be carried out at the same time as serology. The full } \\
\text { usefulness of this assay for follow up during treatment is currently } \\
\text { undetermined. }\end{array}$
\end{tabular}

*Some dogs present a significant decrease in antibody levels (more than a two-fold dilutions difference between the first and the following samples) associated with clinical improvement within 6 months to 1 year of treatment. Other dogs might not have a decrease in antibody levels despite clinical improvement. In contrast, a marked increase of antibody levels (more than two-fold elevation between monitoring samples) should be interpreted as a marker of relapse, especially in dogs following the discontinuation of treatment [27].

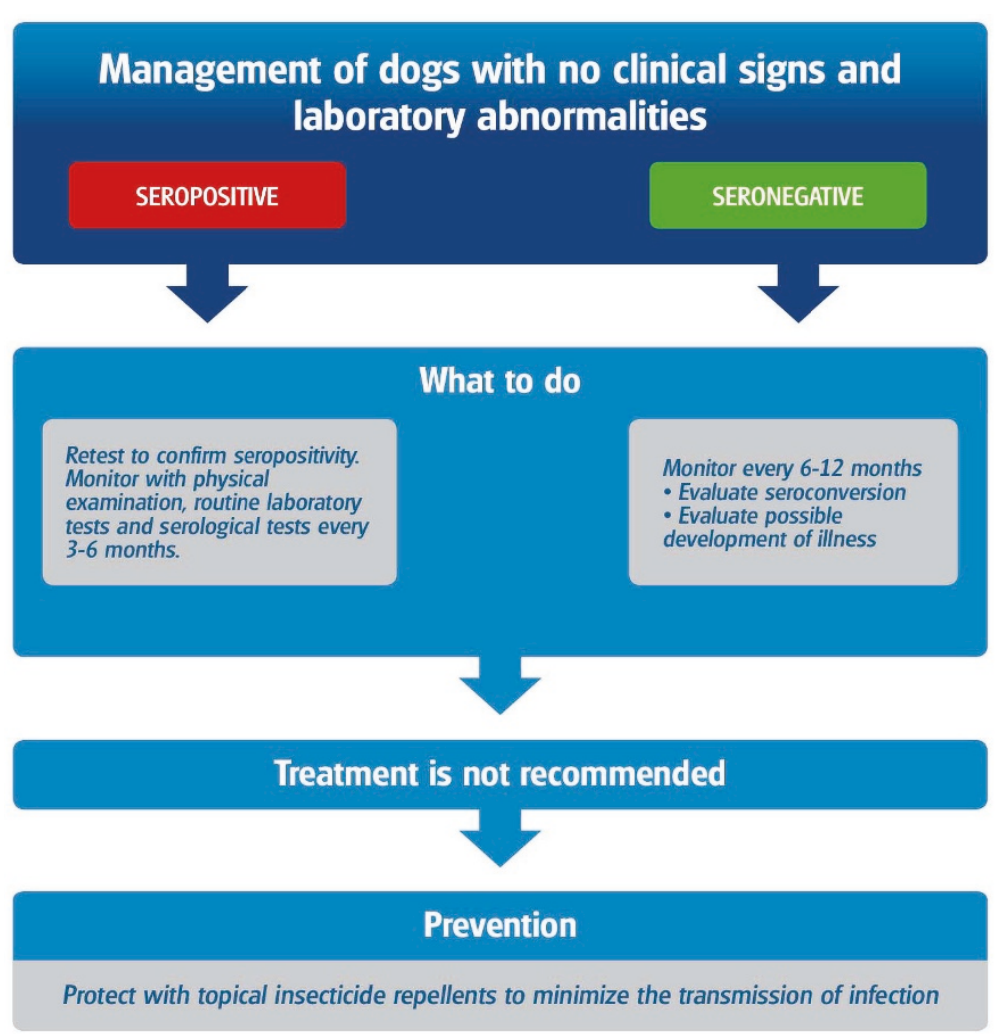

Figure 14 Management of Leishmania-seropositive but clinically healthy dogs and PCR-positive but seronegative dogs. Clinically healthy but seropositive dogs would normally present with low antibody titers and should be confirmed by retesting. Confirmed seropositive dogs should be monitored with physical examinations, routine laboratory tests and serological tests on a regular basis every 3-6 months to assess the progression of infection towards disease.

an effective canine vaccine and the application of a topical insecticide.

\section{List of abbreviations}

AIDS: Acquired Immune Deficiency Syndrome; CanL: Canine leishmaniosis; CBC: Complete blood count; CKD: Chronic kidney disease); DNA:
Deoxyribonucleic acid; ELISA: Enzyme-linked immunosorbent assay; FML: Fucose mannose ligand; IFAT: Immunofluorescence antibody test; IgG: Immunoglobulin G; IRIS: International Renal Interest Society; kDNA: Kinetoplast DNA; MHC II: Major histocompatibility complex type II; N-RAMPI: Natural Resistance-associated Macrophage Protein one; PCR: Polymerase chain reaction; P.O.: per OS; S.C.: subcutaneous; SIc11c1: Solute carrier family 11 member a1; UPC: Urinary protein creatinine ratio; USA: United States of America 


\section{Acknowledgements}

The authors would like to acknowledge Dr. Norbert Mencke and the kind support of Bayer Animal Health GmbH. The authors would like to thank scientists, human physicians and veterinarians that have advanced the understanding of canine leishmaniosis. Publication of this manuscript has been sponsored by Bayer Animal Health GmbH. All authors are members of LeishVet. LeishVet address: Dpto. Sanidad Animal, Facultad de Veterinaria, Universidad Complutense de Madrid, Spain e-mail: leishvet@vet.ucm.es

\section{Author details}

'Dep. Pathology and Infectious Diseases, Royal Veterinary College of London, UK. ${ }^{2}$ Dpto. Sanidad Animal, Facultad de Veterinaria, Universidad Complutense de Madrid, Spain. ${ }^{3}$ Companion Animal Clinic, Faculty of Veterinary Medicine, Aristotle University of Thessaloniki, Greece. ${ }^{4}$ Dep. de Ciências Veterinárias, Universidade de Trás-os-Montes e Alto Douro, Portugal. ${ }^{5}$ Dip.to Sanità Pubblica Veterinaria, Facoltà di Medicina Veterinaria, Polo Universitario Annunziata, Messina, Italy. ${ }^{6}$ Dep. de Medicina i Cirurgia Animals,

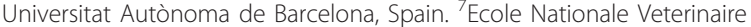
Agroalimentaire et de l'alimentation Nantes-Atlantique (ONIRIS), France. ${ }^{8}$ Dep. of Veterinary Clinical Sciences, Faculty of Veterinary Medicine, University of Naples Federico II, Italy. ${ }^{9}$ School of Veterinary Medicine, Hebrew University, Israel.

\section{Authors' contributions}

LSG, GM, AK, LC, MGP, LF, PB, GO and GB participated in the formation of the manuscript's content. LSG coordinated the preparation and writing of the manuscript. All authors contributed to helpful discussions, read and approved the final manuscript.

\section{Competing interests}

The authors declare that they have no competing interests.

Received: 25 April 2011 Accepted: 20 May 2011 Published: 20 May 2011

\section{References}

1. Gramiccia M, Gradoni L: The current status of zoonotic leishmaniases and approaches to disease control. Int J Parasitol 2005, 35(11-12):1169-1180.

2. Baneth G, Koutinas AF, Solano-Gallego L, Bourdeau P, Ferrer L: Canine leishmaniosis - new concepts and insights on an expanding zoonosis: part one. Trends Parasitol 2008, 24(7):324-330.

3. Petersen CA, Barr SC: Canine leishmaniasis in North America: emerging or newly recognized? Vet Clin North Am Small Anim Pract 2009, 39(6):1065-1074

4. Shaw SE, Langton DA, Hillman TJ: Canine leishmaniosis in the United Kingdom: a zoonotic disease waiting for a vector? Vet Parasitol 2009, 163(4):281-285.

5. Owens SD, Oakley DA, Marryott K, Hatchett W, Walton R, Nolan TJ, Newton A, Steurer F, Schantz P, Giger U: Transmission of visceral leishmaniasis through blood transfusions from infected English foxhounds to anemic dogs. J Am Vet Med Assoc 2001, 219(8):1076-1083.

6. de Freitas E, Melo MN, da Costa-Val AP, Michalick MS: Transmission of Leishmania infantum via blood transfusion in dogs: potential for infection and importance of clinical factors. Vet Parasitol 2006, 137(12):159-167.

7. Tabar MD, Roura X, Francino O, Altet L, Ruiz de Gopegui R: Detection of Leishmania infantum by real-time PCR in a canine blood bank. J Small Anim Pract 2008, 49(7):325-328.

8. Rosypal AC, Troy GC, Zajac AM, Frank G, Lindsay DS: Transplacental transmission of a North American isolate of Leishmania infantum in an experimentally infected beagle. J Parasitol 2005, 91(4):970-972.

9. Pangrazio KK, Costa EA, Amarilla SP, Cino AG, Silva TM, Paixao TA, Costa LF, Dengues EG, Diaz AA, Santos RL: Tissue distribution of Leishmania chagasi and lesions in transplacentally infected fetuses from symptomatic and asymptomatic naturally infected bitches. Vet Parasitol 2009, 165(3-4):327-331.

10. Boggiatto PM, Gibson-Corley KN, Metz K, Gallup JM, Hostetter JM, Mullin K, Petersen CA: Transplacental Transmission of Leishmania infantum as a Means for Continued Disease Incidence in North America. PLoS Negl Trop Dis 2011, 5(4)

11. Silva FL, Oliveira RG, Silva TM, Xavier MN, Nascimento EF, Santos RL: Venereal transmission of canine visceral leishmaniasis. Vet Parasitol 2009, 160(1-2):55-59.
12. Shaw SE, Langton DA, Hillman TJ: Canine leishmaniosis in the United Kingdom: A zoonotic disease waiting for a vector? Vet Parasitol 2009.

13. Duprey ZH, Steurer FJ, Rooney JA, Kirchhoff LV, Jackson JE, Rowton ED, Schantz PM: Canine visceral leishmaniasis, United States and Canada, 2000-2003. Emerg Infect Dis 2006, 12(3):440-446.

14. Chamaille L, Tran A, Meunier A, Bourdoiseau G, Ready P, Dedet JP: Environmental risk mapping of canine leishmaniasis in France. Parasit Vectors 2010, 3:31.

15. Coutinho MT, Bueno LL, Sterzik A, Fujiwara RT, Botelho JR, De Maria M, Genaro O, Linardi PM: Participation of Rhipicephalus sanguineus (Acari: Ixodidae) in the epidemiology of canine visceral leishmaniasis. Vet Parasitol 2005, 128(1-2):149-155.

16. Coutinho MT, Linardi PM: Can fleas from dogs infected with canine visceral leishmaniasis transfer the infection to other mammals? Vet Parasitol 2007, 147(3-4):320-325

17. Dantas-Torres F: Ticks as vectors of Leishmania parasites. Trends Parasitol 2011.

18. Dantas-Torres F, Martins TF, de Paiva-Cavalcanti M, Figueredo LA, Lima BS, Brandao-Filho SP: Transovarial passage of Leishmania infantum KDNA in artificially infected Rhipicephalus sanguineus. Exp Parasitol 2010, 125(2):184-185.

19. Paz GF, Ribeiro MF, Michalsky EM, da Rocha Lima AC, Franca-Silva JC, Barata RA, Fortes-Dias CL, Dias ES: Evaluation of the vectorial capacity of Rhipicephalus sanguineus (Acari: Ixodidae) in the transmission of canine visceral leishmaniasis. Parasitol Res 2010, 106(2):523-528.

20. Paz GF, Ribeiro MF, de Magalhaes DF, Sathler KP, Morais MH, Fiuza VO, Brandao ST, Werneck GL, Fortes-Dias CL, Dias ES: Association between the prevalence of infestation by Rhipicephalus sanguineus and Ctenocephalides felis felis and the presence of anti-Leishmania antibodies: A case-control study in dogs from a Brazilian endemic area. Prev Vet Med 2010, 97(2):131-133.

21. Dantas-Torres F, Stefania Latrofa M, Otranto D: Quantification of Leishmania infantum DNA in females, eggs and larvae of Rhipicephalus sanguineus. Parasit Vectors 2011, 4(1):56.

22. Maroli M, Rossi L, Baldelli R, Capelli G, Ferroglio E, Genchi C, Gramiccia M, Mortarino M, Pietrobelli M, Gradoni L: The northward spread of leishmaniasis in Italy: evidence from retrospective and ongoing studies on the canine reservoir and phlebotomine vectors. Trop Med Int Health 2008, 13(2):256-264.

23. Amusategui I, Sainz A, Aguirre E, Tesouro MA: Seroprevalence of Leishmania infantum in northwestern Spain, an area traditionally considered free of leishmaniasis. Ann N Y Acad Sci 2004, 1026:154-157.

24. Menn B, Lorentz S, Naucke TJ: Imported and travelling dogs as carriers of canine vector-borne pathogens in Germany. Parasit Vectors 2010, 3:34.

25. Peters N, Sacks D: Immune privilege in sites of chronic infection: Leishmania and regulatory T cells. Immunol Rev 2006, 213:159-179.

26. Solano-Gallego L, Morell P, Arboix M, Alberola J, Ferrer L: Prevalence of Leishmania infantum infection in dogs living in an area of canine leishmaniasis endemicity using PCR on several tissues and serology. Clin Microbiol 2001, 39(2):560-563.

27. Solano-Gallego L, Koutinas A, Miro G, Cardoso L, Pennisi MG, Ferrer L, Bourdeau P, Oliva G, Baneth G: Directions for the diagnosis, clinical staging, treatment and prevention of canine leishmaniosis. Vet Parasitol 2009, 165(1-2):1-18.

28. Alvar J, Aparicio P, Aseffa A, Den Boer M, Canavate C, Dedet JP, Gradoni L, Ter Horst R, Lopez-Velez R, Moreno J: The relationship between leishmaniasis and AIDS: the second 10 years. Clin Microbiol Rev 2008, 21(2):334-359.

29. Sideris V, Papadopoulou G, Dotsika E, Karagouni E: Asymptomatic canine leishmaniasis in Greater Athens area, Greece. Eur J Epidemiol 1999, 15(3):271-276

30. Franca-Silva JC, da Costa RT, Siqueira AM, Machado-Coelho GL, da Costa CA, Mayrink W, Vieira EP, Costa JS, Genaro O, Nascimento E: Epidemiology of canine visceral leishmaniosis in the endemic area of Montes Claros Municipality, Minas Gerais State, Brazil. Vet Parasitol 2003, 111(2-3):161-173.

31. Solano-Gallego L, Llull J, Ramos G, Riera C, Arboix M, Alberola J, Ferrer L: The Ibizian hound presents a predominantly cellular immune response against natural Leishmania infection. Vet Parasitol 2000, 90(1-2):37-45.

32. Quinnell RJ, Kennedy LJ, Barnes A, Courtenay O, Dye C, Garcez LM, Shaw MA, Carter SD, Thomson W, Ollier WE: Susceptibility to visceral 
leishmaniasis in the domestic dog is associated with MHC class II polymorphism. Immunogenetics 2003, 55(1):23-28.

33. Sanchez-Robert E, Altet L, Utzet-Sadurni M, Giger U, Sanchez A, Francino O: Slc11a1 (formerly Nramp1) and susceptibility to canine visceral leishmaniasis. Vet Res 2008, 39(3):36.

34. Abranches P, Silva-Pereira MC, Conceicao-Silva FM, Santos-Gomes GM, Janz JG: Canine leishmaniasis: pathological and ecological factors influencing transmission of infection. J Parasitol 1991, 77(4):557-561.

35. Cardoso L, Schallig HD, Neto F, Kroon N, Rodrigues M: Serological survey of Leishmania infection in dogs from the municipality of Peso da Regua (Alto Douro, Portugal) using the direct agglutination test (DAT) and fast agglutination screening test (FAST). Acta Trop 2004, 91(2):95-100.

36. Ciaramella P, Oliva G, Luna RD, Gradoni L, Ambrosio R, Cortese L, Scalone A, Persechino A: A retrospective clinical study of canine leishmaniasis in 150 dogs naturally infected by Leishmania infantum. Vet Rec 1997, 141(21):539-543.

37. Koutinas AF, Polizopoulou ZS, Saridomichelakis MN, Argyriadis D, Fytianou A, Plevraki KG: Clinical considerations on canine visceral leishmaniasis in Greece: a retrospective study of 158 cases (1989-1996). J Am Anim Hosp Assoc 1999, 35(5):376-383.

38. Costa FA, Goto H, Saldanha LC, Silva SM, Sinhorini IL, Silva TC, Guerra JL: Histopathologic patterns of nephropathy in naturally acquired canine visceral leishmaniasis. Vet Pathol 2003, 40(6):677-684.

39. Zatelli A, Borgarelli M, Santilli R, Bonfanti U, Nigrisoli E, Zanatta R, Tarducci A, Guarraci A: Glomerular lesions in dogs infected with Leishmania organisms. Am J Vet Res 2003, 64(5):558-561.

40. Solano-Gallego L, Fernandez-Bellon H, Morell P, Fondevila D, Alberola J, Ramis A, Ferrer L: Histological and immunohistochemical study of clinically normal skin of Leishmania infantum-infected dogs. J Comp Pathol 2004, 130(1):7-12.

41. Pena MT, Naranjo C, Klauss G, Fondevila D, Leiva M, Roura X, Davidson MG, Dubielzig RR: Histopathological features of ocular leishmaniosis in the dog. J Comp Pathol 2008, 138(1):32-39.

42. Petanides TA, Koutinas AF, Mylonakis ME, Day MJ, Saridomichelakis MN, Leontides LS, Mischke R, Diniz P, Breitschwerdt EB, Kritsepi M, et al: Factors associated with the occurrence of epistaxis in natural canine leishmaniasis (Leishmania infantum). J Vet Intern Med 2008, 22(4):866-872

43. Mylonakis ME, Papaioannou N, Saridomichelakis MN, Koutinas AF, Billinis C, Kontos VI: Cytologic patterns of lymphadenopathy in dogs infected with Leishmania infantum. Vet Clin Pathol 2005, 34(3):243-247.

44. Mettler M, Grimm F, Capelli G, Camp H, Deplazes P: Evaluation of enzymelinked immunosorbent assays, an immunofluorescent-antibody test, and two rapid tests (immunochromatographic-dipstick and gel tests) for serological diagnosis of symptomatic and asymptomatic Leishmania infections in dogs. J Clin Microbiol 2005, 43(11):5515-5519.

45. Mohebali M, Taran M, Zarei Z: Rapid detection of Leishmania infantum infection in dogs: comparative study using an immunochromatographic dipstick rk39 test and direct agglutination. Vet Parasitol 2004, 121(34):239-245.

46. Ferroglio E, Centaro E, Mignone W, Trisciuoglio A: Evaluation of an ELISA rapid device for the serological diagnosis of Leishmania infantum infection in dog as compared with immunofluorescence assay and Western blot. Vet Parasitol 2007, 144(1-2):162-166.

47. Maia C, Ramada J, Cristovao JM, Goncalves L, Campino L: Diagnosis of canine leishmaniasis: conventional and molecular techniques using different tissues. Vet J 2009, 179(1):142-144.

48. Solano-Gallego L, Rodriguez-Cortes A, Trotta M, Zampieron C, Razia L, Furlanello T, Caldin M, Roura X, Alberola J: Detection of Leishmania infantum DNA by fret-based real-time PCR in urine from dogs with natural clinical leishmaniosis. Vet Parasitol 2007, 147(3-4):315-319.

49. Maia C, Campino L: Methods for diagnosis of canine leishmaniasis and immune response to infection. Vet Parasitol 2008, 158(4):274-287.

50. Miro G, Cardoso L, Pennisi MG, Oliva G, Baneth G: Canine leishmaniosisnew concepts and insights on an expanding zoonosis: part two. Trends Parasitol 2008, 24(8):371-377.

51. Pennisi MG, Reale S, Giudice SL, Masucci M, Caracappa S, Vitale M, Vitale F: Real-time PCR in dogs treated for leishmaniasis with allopurinol. Vet Res Commun 2005, 29(Suppl 2):301-303.
52. Manna L, Reale S, Vitale F, Picillo E, Pavone LM, Gravino AE: Real-time PCR assay in Leishmania-infected dogs treated with meglumine antimoniate and allopurinol. Vet J 2008, 177(2):279-282.

53. Reis AB, Teixeira-Carvalho A, Vale AM, Marques MJ, Giunchetti RC, Mayrink W, Guerra LL, Andrade RA, Correa-Oliveira R, Martins-Filho OA: Isotype patterns of immunoglobulins: hallmarks for clinical status and tissue parasite density in Brazilian dogs naturally infected by Leishmania (Leishmania) chagasi. Vet Immunol Immunopathol 2006, 112(3-4):102-116.

54. Noli C, Auxilia ST: Treatment of canine Old World visceral leishmaniasis: a systematic review. Vet Dermatol 2005, 16(4):213-232.

55. Ikeda-Garcia FA, Lopes RS, Marques FJ, de Lima VM, Morinishi CK, Bonello FL, Zanette MF, Perri SH, Feitosa MM: Clinical and parasitological evaluation of dogs naturally infected by Leishmania (Leishmania) chagasi submitted to treatment with meglumine antimoniate. Vet Parasitol 2007, 143(3-4):254-259.

56. Ribeiro RR, Moura EP, Pimentel VM, Sampaio WM, Silva SM, Schettini DA, Alves CF, Melo FA, Tafuri WL, Demicheli C, et al: Reduced tissue parasitic load and infectivity to sand flies in dogs naturally infected by Leishmania (Leishmania) chagasi following treatment with a liposome formulation of meglumine antimoniate. Antimicrob Agents Chemother 2008.

57. Miro G, Galvez R, Fraile C, Descalzo MA, Molina R: Infectivity to Phlebotomus perniciosus of dogs naturally parasitized with Leishmania infantum after different treatments. Parasites and vectors

58. Pennisi MG, De Majo M, Masucci M, Britti D, Vitale F, Del Maso R: Efficacy of the treatment of dogs with leishmaniosis with a combination of metronidazole and spiramycin. Vet Rec 2005, 156(11):346-349.

59. Torres M, Bardagi M, Roura X, Zanna G, Ravera I, Ferrer L: Long term follow-up of dogs diagnosed with leishmaniosis (clinical stage II) and treated with meglumine antimoniate and allopurinol. Vet J 2011, 188(3):346-351.

60. Oliva G, Scalone A, Foglia Manzillo V, Gramiccia M, Pagano A, Di Muccio T, Gradoni L: Incidence and time course of Leishmania infantum infections examined by parasitological, serologic, and nested-PCR techniques in a cohort of naive dogs exposed to three consecutive transmission seasons. J Clin Microbiol 2006, 44(4):1318-1322

61. Miro G, Galvez R, Mateo M, Montoya A, Descalzo MA, Molina R: Evaluation of the efficacy of a topically administered combination of imidacloprid and permethrin against Phlebotomus perniciosus in dog. Vet Parasitol 2007, 143(3-4):375-379.

62. Mencke N, Volf P, Volfova V, Stanneck D: Repellent efficacy of a combination containing imidacloprid and permethrin against sand flies (Phlebotomus papatasi) in dogs. Parasitol Res 2003, 90(Suppl 3):S108-111.

63. Killick-Kendrick R, Killick-Kendrick M, Focheux C, Dereure J, Puech MP, Cadiergues MC: Protection of dogs from bites of phlebotomine sandflies by deltamethrin collars for control of canine leishmaniasis. Med Vet Entomol 1997, 11(2):105-111.

64. Otranto D, Paradies P, Lia RP, Latrofa MS, Testini G, Cantacessi C, Mencke N, Galli G, Capelli G, Stanneck D: Efficacy of a combination of $10 \%$ imidacloprid $/ 50 \%$ permethrin for the prevention of leishmaniasis in kennelled dogs in an endemic area. Vet Parasitol 2007, 144(3-4):270-278.

65. Maroli M, Mizzon V, Siragusa C, D'Oorazi A, Gradoni L: Evidence for an impact on the incidence of canine leishmaniasis by the mass use of deltamethrin-impregnated dog collars in southern Italy. Med Vet Entomol 2001, 15(4):358-363.

66. Foglia Manzillo V, Oliva G, Pagano A, Manna L, Maroli M, Gradoni L: Deltamethrin-impregnated collars for the control of canine leishmaniasis: evaluation of the protective effect and influence on the clinical outcome of Leishmania infection in kennelled stray dogs. Vet Parasitol 2006, 142(1-2):142-145

67. Otranto D, de Caprariis D, Lia RP, Tarallo V, Lorusso V, Testini G, DantasTorres F, Latrofa S, Diniz PP, Mencke N, et al: Prevention of endemic canine vector-borne diseases using imidacloprid $10 \%$ and permethrin 50\% in young dogs: a longitudinal field study. Vet Parasitol 2010, 172(34):323-332.

68. Gavgani AS, Hodjati MH, Mohite H, Davies CR: Effect of insecticideimpregnated dog collars on incidence of zoonotic visceral leishmaniasis in Iranian children: a matched-cluster randomised trial. Lancet 2002, 360(9330):374-379. 
69. Alexander B, Maroli M: Control of phlebotomine sandflies. Med Vet Entomol 2003, 17(1):1-18

70. Maroli M, Gradoni L, Oliva G, Castagnaro M, Crotti A, Lubas G, Paltrinieri S, Roura X, Zini E, Zatelli A: Guidelines for prevention of leishmaniasis in dogs. J Am Vet Med Assoc 2010, 236(11):1200-1206.

71. Rossi E, Bongiorno G, Ciolli E, Di Muccio T, Scalone A, Gramiccia M, Gradoni L, Maroli M: Seasonal phenology, host-blood feeding preferences and natural Leishmania infection of Phlebotomus perniciosus (Diptera, Psychodidae) in a high-endemic focus of canine leishmaniasis in Rome province, Italy. Acta Trop 2008, 105(2):158-165

72. Borja-Cabrera GP, Correia Pontes NN, da Silva VO, Paraguai de Souza E, Santos WR, Gomes EM, Luz KG, Palatnik M, Palatnik de Sousa CB: Long lasting protection against canine kala-azar using the FML-QuilA saponin vaccine in an endemic area of Brazil (Sao Goncalo do Amarante, RN). Vaccine 2002, 20(27-28):3277-3284.

73. Palatnik-de-Sousa CB, Barbosa Ade F, Oliveira SM, Nico D, Bernardo RR, Santos WR, Rodrigues MM, Soares I, Borja-Cabrera GP: FML vaccine against canine visceral leishmaniasis: from second-generation to synthetic vaccine. Expert Rev Vaccines 2008, 7(6):833-851.

74. Lemesre JL, Holzmuller P, Goncalves RB, Bourdoiseau G, Hugnet C, Cavaleyra M, Papierok G: Long-lasting protection against canine visceral leishmaniasis using the LiESAp-MDP vaccine in endemic areas of France: double-blind randomised efficacy field trial. Vaccine 2007, 25(21):4223-4234.

75. Saraiva EM, de Figueiredo Barbosa A, Santos FN, Borja-Cabrera GP, Nico D, Souza LO, de Oliveira Mendes-Aguiar C, de Souza EP, Fampa P, Parra LE, et al: The FML-vaccine (Leishmune) against canine visceral leishmaniasis: a transmission blocking vaccine. Vaccine 2006, 24(13):2423-2431.

76. Fernandes AP, Costa MM, Coelho EA, Michalick MS, de Freitas E, Melo MN Luiz Tafuri W, Resende Dde M, Hermont V, Abrantes Cde F, et al: Protective immunity against challenge with Leishmania (Leishmania) chagasi in beagle dogs vaccinated with recombinant A2 protein. Vaccine 2008, 26(46):5888-5895.

77. Diza E, Kansouzidou A, Gerou S, Vezyri E, Metallidis S, Antoniadis A: Leishmaniases in Northern Greece: seroprevalence of the infection and incidence of the disease during the period 2001-2006. Eur J Clin Microbiol Infect Dis 2008, 27(10):997-1003.

78. Marty P, Izri A, Ozon C, Haas P, Rosenthal E, Del Giudice P, Godenir J, Coulibaly E, Gari-Toussaint M, Delaunay P, et al: A century of leishmaniasis in Alpes-Maritimes, France. Ann Trop Med Parasitol 2007, 101(7):563-574.

79. IRIS staging of chronic renal disease. [http://www.ris-kidney.com/ guidelines/en/staging_ckd.shtml].

80. IRIS treatment recommendation. [http://www.iris-kidney.com/guidelines/ en/treatment_recommendations.shtml].

81. Denerolle P, Bourdoiseau G: Combination allopurinol and antimony treatment versus antimony alone and allopurinol alone in the treatment of canine leishmaniasis (96 cases). J Vet Intern Med 1999, 13(5):413-415.

82. Bianciardi P, Brovida C, Valente M, Aresu L, Cavicchioli L, Vischer C, Giroud L, Castagnaro M: Administration of miltefosine and meglumine antimoniate in healthy dogs: clinicopathological evaluation of the impact on the kidneys. Toxicol Pathol 2009, 37(6):770-775.

83. Miro G, Oliva G, Cruz I, Canavate C, Mortarino M, Vischer C, Bianciardi P: Multicentric, controlled clinical study to evaluate effectiveness and safety of miltefosine and allopurinol for canine leishmaniosis. Vet Dermatol 2009, 20(5-6):397-404.

84. Mateo M, Maynard L, Vischer C, Bianciardi P, Miro G: Comparative study on the short term efficacy and adverse effects of miltefosine and meglumine antimoniate in dogs with natural leishmaniosis. Parasitol Res 2009, 105(1):155-162.

85. Manna L, Vitale F, Reale S, Picillo E, Neglia G, Vescio F, Gravino AE: Study of efficacy of miltefosine and allopurinol in dogs with leishmaniosis. Vet J 2009, 182(3):441-445.

86. Koutinas AF, Saridomichelakis MN, Mylonakis ME, Leontides L, Polizopoulou Z, Billinis C, Argyriadis D, Diakou N, Papadopoulos O: A randomised, blinded, placebo-controlled clinical trial with allopurinol in canine leishmaniosis. Vet Parasitol 2001, 98(4):247-261.

87. Plevraki K, Koutinas AF, Kaldrymidou H, Roumpies N, Papazoglou LG Saridomichelakis MN, Savvas I, Leondides L: Effects of allopurinol treatment on the progression of chronic nephritis in Canine leishmaniosis (Leishmania infantum). J Vet Intern Med 2006, 20(2):228-233.
88. Cavaliero T, Arnold P, Mathis A, Glaus T, Hofmann-Lehmann R, Deplazes P: Clinical, serologic, and parasitologic follow-up after long-term allopurinol therapy of dogs naturally infected with Leishmania infantum. J Vet Intern Med 1999, 13(4):330-334.

89. Ling GV, Ruby AL, Harrold DR, Johnson DL: Xanthine-containing urinary calculi in dogs given allopurinol. J Am Vet Med Assoc 1991, 198(11):1935-1940.

doi:10.1186/1756-3305-4-86

Cite this article as: Solano-Gallego et al:: LeishVet guidelines for the practical management of canine leishmaniosis. Parasites \& Vectors 2011 $4: 86$

\section{Submit your next manuscript to BioMed Central and take full advantage of:}

- Convenient online submission

- Thorough peer review

- No space constraints or color figure charges

- Immediate publication on acceptance

- Inclusion in PubMed, CAS, Scopus and Google Scholar

- Research which is freely available for redistribution

Submit your manuscript at www.biomedcentral.com/submit
Ciomed Central 